浮游性珪藻 Synedra の増殖傾向ならびに形態の変異

横浜市水道局 小出悟郎

A study on the growth and form variation planktonic diatom Synedra

by Goro Koide

\section{は じめに}

珪藻類の Synedra 属の内 Plankton 生活をする2, 3 の種類はしばしば湖や貯水池に大量に增殖し, 湖や貯 水池を水源とする上水道施設では沪過池の砂層上部に堆 積して沪過池が閉塞する障害を起している。1）2）3）た Synedra 涊水に異臭をつけるともいわれている。4)

浮游性の Synedra には Synedra ulna の変種と Synedra acus ならびに同種の変種, Synedsa rumpeus, Synedra minuscula5)6)などが知られているが，沪過障 害を起寸種類は主として Synedra ulna, Synedra acus のそれぞれの変種である。

筆者は横浜市水道の水源である相模湖で1954年から19 70 年の17年間に增殖した浮游性のSynedra について増 殖傾向を水温ならびにアルカリ度の傾向から検討し，さ らに相模湖拉よび琵琶湖, 芦の湖, 愛知池 (愛知県) の 浮游性のSynedra ulna, Synedra acus の殸長, 殸巾, 条線数 (Striae) について計測し, 形態的な比較検討を 行なった。

本文に入るに先立ち, 本研究に協力され種々の助言を くださった横浜市水道局水質試験所，菅野明男所長はじ め同所員各位に深謝する。特に磯村康博, 青木節男両君 にはP Plankton の計数をわずらわせた，その労に感謝の 意を表する。

\section{調査方法と試料}

\section{1) 増殖傾向の調查}

1954年から1970年の17年間毎月 1 回相模湖で行なった 定期調査の資料7) から Synedra の增殖状況, 水温, 了 ルカリ度のデーターと, 相模湖を水源とする西谷浄水場 着水井水の1970年のデーターを整理検討した。

2 ) 形態の調査

試料は相模湖の 1954 年 8 月, 1957 年 4 月と 7 月, 1967 年 2 月, 1968年 9 月の 5 試料と琵琶湖の 1970 年 6 月, 芦 の湖1969年 8 月, 愛知池1968年12月の 3 試料, 計 8 試料 でいずれもSynedra が優占的に増殖しな時期に採取し たものである。
これらの試料は過マンガン酸カリウム $\left(\mathrm{KMnO}_{4}\right)$ によ る酸処理8)ののち, プリウラックスで封じ永久プレパラ 一トとして個々の細胞の写真をとり, 写真から殼長, 殼 巾ならびに $10 \mu$ 中の Striae 数を測定した。なお Striae と殼巾は図 1 に示すように中央結節 (Central area) に接 するところで測定した。

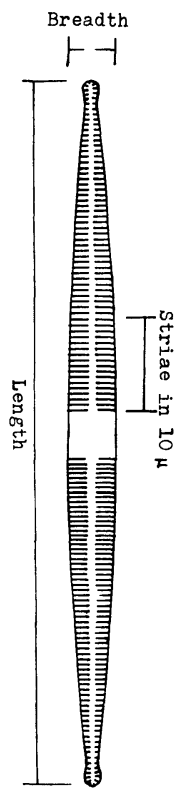

図 1. Synedra の模式図

\section{調査成績と考察}

1) 増殖傾向

相模湖の表層水について毎月 1 回行なった調査から19 54年〜1970年の17年間の浮游性の Synedra ulna と Synedra acus の增殖状況を示すと図 2 の如くである。

同湖水の Synedra が $20 \mathrm{cell} / \mathrm{ml}$ 以上になった場合を 一応増殖状況にあったと見ると，増殖の時期は 3 月から 12月の長期に及んだ。

(1) 水温

相模湖の Synedra の增殖について月別の出現頻度は 


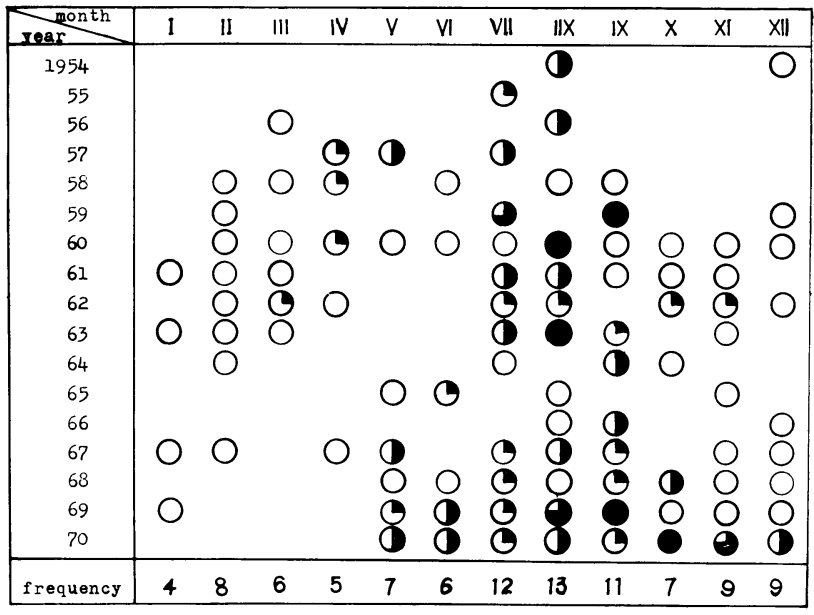

cell/ $1 \mathrm{ml}$

$$
\bigcirc_{501-1000}^{1-20} \bigcirc_{1001-15000}^{21-100} 101-500
$$

図 2. 相模湖における1954年から1970年の間の Synedra の増殖傾向

7 月〜 9 月が大きく, 一応夏季の高水温が増殖に適する ように見られる。しかし11，12月と 2 月の冬季の低水温 時でもSynedra がしばしば出現しており, 增殖が起っ
た時期の水温は $\max .29 .0^{\circ} \mathrm{C}, \min .6 .8^{\circ} \mathrm{C}$, range は22. $2^{\circ} \mathrm{C}$ とが広い。

また筆者は相模湖に接続する津久井湖（人工 湖）で 1967 年 2 月に Synedra が $200 \mathrm{cell} / \mathrm{ml}$ に及んだ増殖を記録しており9)，当時の水温は 4.5〜 $11.0^{\circ} \mathrm{C}$ であった。

(2) アルカリ度

i ) 符号検定 ${ }^{10}$

相模湖に増殖した珪藻の内, Synedra, Cyclotella (Stephanndiscus を含む), Fragilaria とアルカリ度の増減を図 3 のごとく, 藻類の細 胞数 (Fragilaria では群体数) が前回の調查時 より増加した場合 $(+)$, 減少した場合 $($ 一), 横 ばいを(0)とし, 同様にアルカリ度の上昇を $(+)$, 下降を $(-)$, 横ばいを $(0)$ とすると, 藻 類とアルカリ度との符号が同じ場合（+十また はーー)，符号が異なる場合 $(+$ はたは一+)， 藻類とアルカリ度のいずれか一方が 0 となる場 合とがあり，以上の符号の関係を 17 年間で集計 したものが表 1 である。

表 1 の各々の種類について二項確率紙に符号が同じ場 合を縦軸に，符号の異なる場合を横軸にとり，実測三角

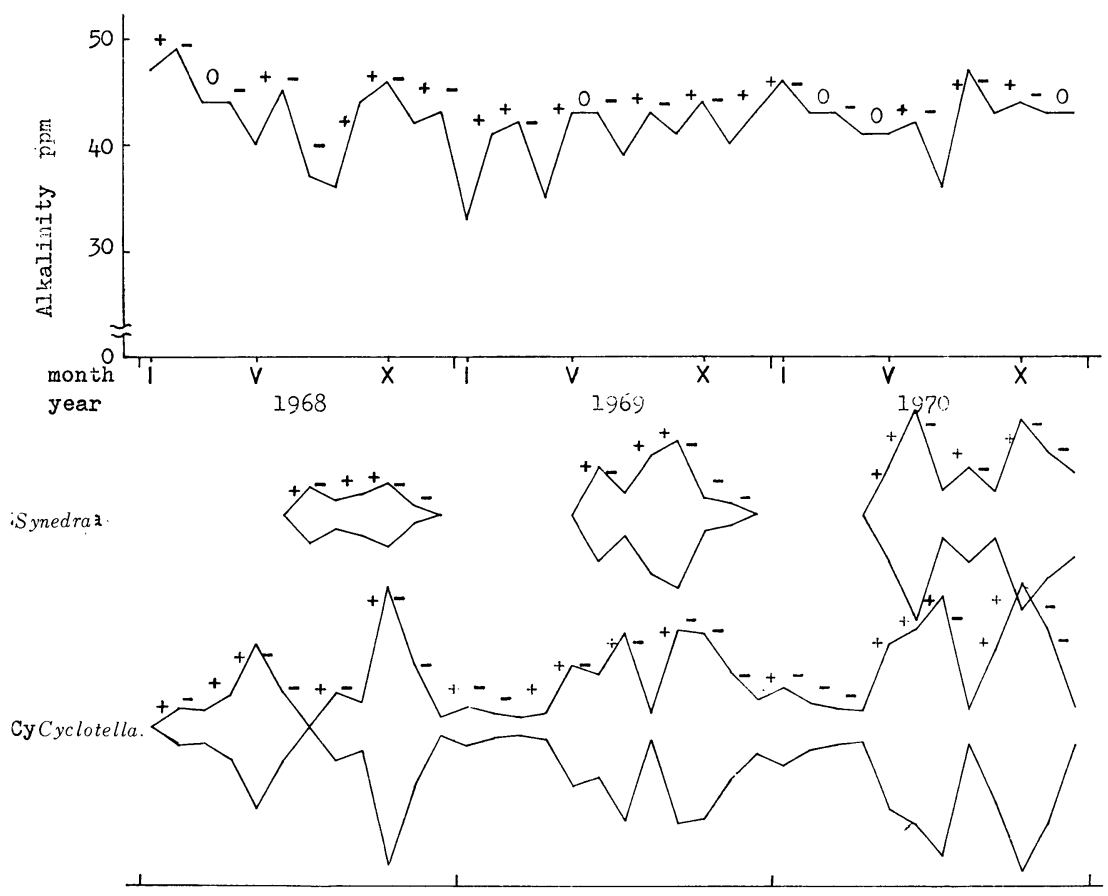

図 3. 相模湖における藻類の消長とアルカリ度の変動の符号検定の例 
表 1 藻類とアルカリ度の増減の符号の関係

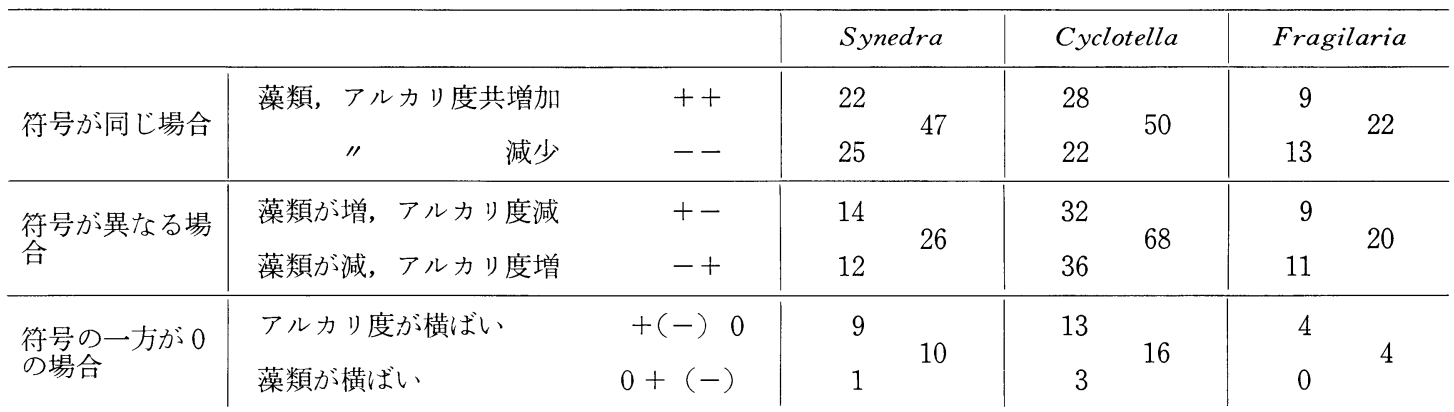

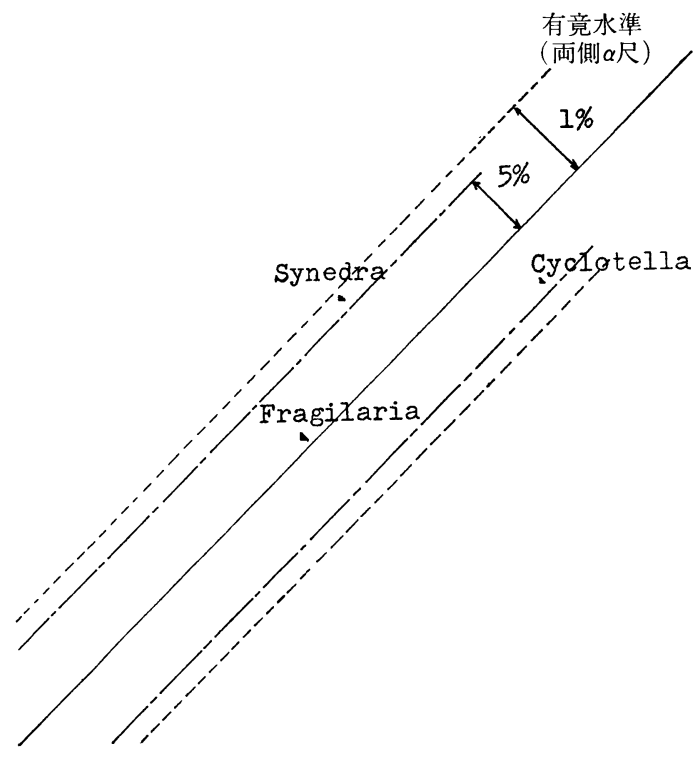

図 4. 二項確率紙での藻類とアルカリ度の符号検定

\section{形を党がくと図 4 の如くなる。}

すなわち Synedra では実測点 $(47,26)$ は $50 \%$ 按分 線に対し両側に平行に引かれた有意水準 $5 \%$ の線外にあ り, Cyclotella と Fragilaria では実測点が線内にある。 したがって各種類の増殖とアルカリ度の増減の関係は Synedra の及有意水準 $5 \%$ で有意であり，Cyclotella と Fragilariaは関係があるとはいえない。

ii) 度数分布方平均值

Synedra の増殖した場合と増殖時以外のそれぞれの アルカリ度のヒストグラムを図5に示した。

Synedra の增殖時のアルカリ度は一般に高く, 增殖時 以外のアルカリ度のヒストグラムに比較して山は右にず れた型となる。それぞれの平均值, 分散, 最高最低值と range は表 2 亿示した。

増殖時之増殖時以外のアルカリ度の平均值が異なって いるので，両者の母平均の差の検定を行ならと次の如く

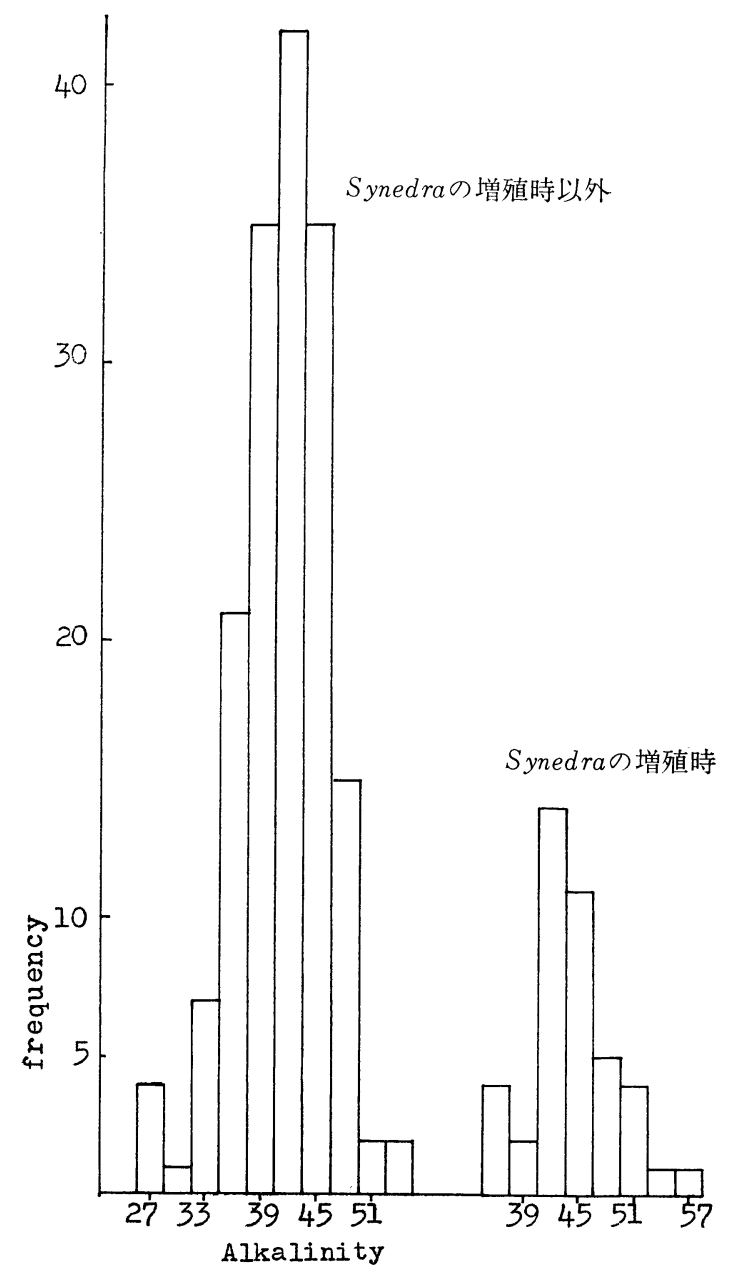

図 5.アルカリ度のヒストグラム

である。

母平均の差の検定

(1) $H_{0}: \mu_{A}=\mu_{B}$

(2) 表 2 より, $\bar{x}_{A}=44.3, \bar{x} B=41.4$, $s_{A}{ }^{2}=22.087, s_{B}{ }^{2}=21.407, n_{A}=42, n_{B}=163$ 
表 2 Synedra の增殖時と增殖時以外の時のアルカリ度の平均値, 分散, 最高, 最低値と range

\begin{tabular}{rr|r|r|r|r|r}
\hline & mean & variance & max. & min. & range \\
\hline Synedra & 増 殖 期 & 44.3 & 22.087 & 36 & 57 & 21 \\
& 増殖期以外 & 41.4 & 21.407 & 26 & 55 & 29
\end{tabular}

(3) $Z_{o}=\frac{\bar{x}_{A}-\bar{x}^{B}}{\sqrt{\frac{\sigma_{A}{ }^{2}}{n_{A}}+\frac{\sigma_{B}{ }^{2}}{n_{B}}}}=\frac{44.3-41.4}{\sqrt{\frac{22.087}{42}+\frac{21.407}{163}}}=3.58$

(4) $Z_{o}>1.96 \therefore$ 危険率 $5 \%$ で $\mu_{A} \neq \mu_{B}$

但し，増殖時の標本数 $n_{A}$ が 42 と小さいので $s_{A}{ }^{2}=$ 22.087 を $\sigma_{A}{ }^{2}$ に代入することはいささか問題がある。

すなわち, 增殖時と增殖時以外とではアルカリ度の母 平均が異なっているといえそらである。

iii）浄水場着水井水での比較

横浜市の西谷浄水場は相模湖を水源としており, 同浄 水場の着水井水では 1 週間に 2 乃至 3 回の生物定量と毎 日 1 回アルカリ度の測定を行なっている。

したがって相模湖での毎月 1 回の調査よりもアルカリ 度, 藻類の遷移は詳細に知ることができる。しかし同湖 より着水井に水が到達するに要する時間は 2 乃至 3 日で, 途中貯水量 $883,000 \mathrm{~m}^{3}$ の相模原沈殿池を経由寸る。しか も同沈殿池では Synedra のような水道障害生物の増殖 が著るしい時は殺藻処理のため硫酸銅の注入を行ならの で着水井水の生物数, アルカリ度は相模湖の状況そのも のとはいえないが，打拈よその傾向は知ることができる。

図 6 に1970年の 着水井水で Synedra の增加した期間
の細胞数とアルカリ度の移動平均（3 日週期）ならびに 相模原沈殿池での硫酸銅注入状沉を示した。

Synedra の第 1 回目の增殖は 6 月上旬上り起り，6月 8 日に増加の山が見られた。この増加の傾向はアルカリ 度の上昇と一致している。そのご17日にアルカリ度が下 降すると共に Synedra も減少した。

第 2 回目の増殖は 6 月下旬より 8 月下旬の約 2 ケ月間 にわたったが、この期間中増加の山は 4 回あり, 細胞数 は回を追らごとに増加している。また減少の谷は 3 回あ り, はじめの谷はアルカリ度の一時的減少と同時に起っ た。あとの 2 回は硫酸銅による殺藻処理を行なった後に おこっており，殺藻処理の効果が大きいと考兄られる。

この第 2 回目の增殖期のアルカリ度は一時的な減少は あったにしても 6 月下旬より 8 月下旬の全期間を通じて 上昇の傾向が吠められた。

第 3 回目の增殖期は 9 月中旬から翌1971年 3 月におよ ぶ長期間にわたったが，9月上旬から中旬にかけてアル カリ度の上昇があり，これよりやや遅れて Synedraは 增加し，10月10日にアルカリ度が $45 \mathrm{ppm}$ と高い值にな った時 Synedra も $2,000 \mathrm{cell} / \mathrm{ml}$ と最高の細胞数となっ ている。

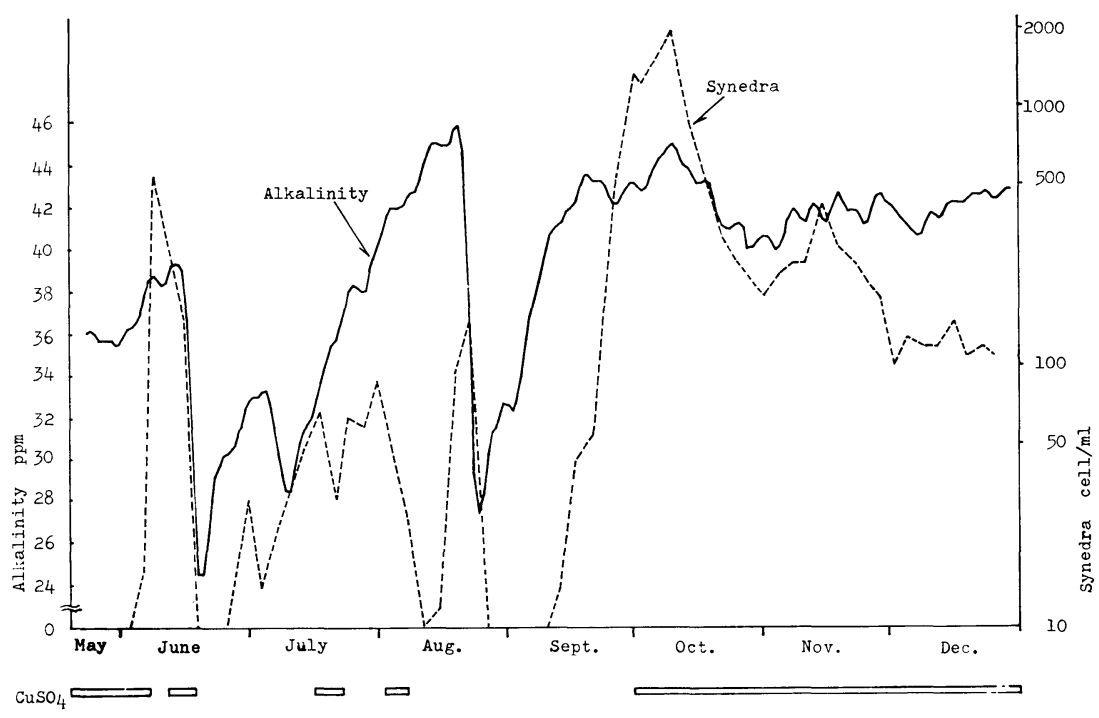

図 6. 西谷浄水場着水井に拈ける1970年の Synedra の消長とアルカリ度の移動平均 並びに相模原沈殿池の硫酸銅注入状沙 
そのごアルカリ度は 41 ～ $43 \mathrm{ppm}$ とわずかに下降した のち横ばいの状況で12月末まで続いているが，Synedra は10月中旬に $200 \sim 300 \mathrm{cell} / \mathrm{ml}$ に減少し，以後 $100 \mathrm{cell} /$ $\mathrm{ml}$ 程度で12月末まで細胞数は横ばい状況であった。

10月中旬の Synedra の減少は 9 月末から硫酸銅の注 入が行なわれており，また10月中旬にはアルカリ度も 2 〜3 ppm 減少しているので, 殺藻処理の効果かアルカリ 度の下降が原因か判然としない。

(3) 考察

珪藻の増殖には幾多の要因が考えられるが最も普通に は水温, 日光, 栄養塩類などが考えられる。

珪藻の増殖にたいする水温の影響について小久保11)

は「それがまだ冬期最低に止まっているらちに珪藻の増 殖を始めることもあり, また珪藻増殖時の水温が地方に よって異なること, 同一地方でも年によって水温が異な る等のことによっても水温の支配力が第一義的なもので ないことがわかる」とし，また一方では浮游性の淡水産 Synedraの増殖適温は $10^{\circ} \mathrm{C}$ と記述している。

相模湖に増殖した Synedra では増殖が起った時期の 水温は範囲が広く，一般に夏季に多く増殖するが冬季で もしばしば増殖しており, したがって水温は増殖要因と して一義的でなく，増殖適温の推定はできない。

次いで栄養塩類では藻類の増殖の制限要因といわれる 燐, 窒素類のデーターが充分でなく，アルカリ度につい てのみ検討した。

アルカリ度は普通, 水中の重炭酸塭, 炭酸塩または水 酸化物などのアルカリ分を炭酸カルシウムの ppm で表 わしたものである。12)

藻類は水に溶解している炭酸 $\left(\mathrm{CO}_{2}, \mathrm{HCO}_{3}\right)$ を利用し, 光合成により炭素を同化して増殖する。したがって水中 の炭酸の存在は窒素や燐などの栄養塩類と同様, 藻類の 増殖の要因として重要であろう。

松江, 平野13) は養鰻池でのアルカリ度, 水温, $\mathrm{pH}$ の正確な測定が “水変り”之呼ばれる藻類の増殖の予知 に必要であることを述べている。

また里見14)は Chlorella と Scenedesmus の培養実験 から栄養塩類の窒素と燐の比とアルカリ度の関係を「増 殖率に影響を及ぼす要因の内, 重炭酸イオン $\left(\mathrm{HCO}_{3}\right)$ を 利用し難い Chlorella ではアルカリ度についで N-P 比 が, $\mathrm{HCO}_{3}$ を利用し得る Scenedesmus では N-P 比に ついでアルカリ度が重視されればならない」とのべ,さ らに Scenedesmusにお打る $\mathrm{HCO}_{3}$ の生体内代謝径路に ついて推定を行なった。

Synedra は $\mathrm{HCO}_{3}$ を利用し得るか否か明らかでない が, 同種の相模湖での増殖傾向とアルカリ度の増減とは 符号検定によって有意の関係があり，また増殖時のアル
カリ度と増殖時以外のアルカリ度とを比較すると前者の 方が一般的に高く，母平均でも有意差がありそらなこと， さらに西谷浄水場着水井に打る Synedra の増減とア ルカリ度の増減とがかなり一致するなど, Synedraの増 殖の要因としてアルカリ度は重要であり，アルカリ度の 上昇期には Synedra の増殖が起りやすいといえそうで ある。

\section{2) 形態の変化}

相模湖のSynedra が前述の如く水温や季節にあまり 関係なく増殖するのは, 出現する種類が増殖期により異 なるのではないかと疑がわれた。

そこで同湖に出現した Synedra ulna と Synedra acus について形態的な变化を検討し, さらに琵琶湖, 芦の湖 および愛知池のこれらの種類とも比較した。

各試料の個々の細胞の写真の一部を図 7,8 に示した。

(1) 外観

i ) Synedra ulna

相模湖の Synedra ulna の浮游性種（図 7-1～4）は 増殖した年や時期が異なっても頭端部, 疑縦溝(Pseudoraphe)ならびに中心区 (Centralarea)などの形状は区別 しがたい。

声の湖（図 7-5）のものは頭端部が卵形に広がり先 端がとがった var. spathulifera 型（図7-5c）ある いは首形になった var. danica 型（図 $7-5$ a) 両者の 中間形と変化に富又, 相模湖のものとは区別し得る。

ii) Synedra acus

相模湖の種類 (図 8-1〜3) は細長いもの, 太く短か いものなど変化に富んでいるが, この変化には増殖の年 や時期での特徴は認められない。

芦の湖（図 8-4）のものは細長く, 繊細であり, 愛 知池（図 8-5) では太く短かい。琵琶湖（図 8-6) のものは相模湖のものと同様変化に富み, 外観からは相 模湖産と琵琶湖産の区別はできない。

(2) 計測值からの比較

殼長，款巾ならびに $10 \mu$ 中の条線数 (Striae) の統計 值を表 3 に，なた図 9 は計測值を図示したものである。

図 9 では殼長, 殸巾は平均值を, Striae はモードを十 印で, 直線で示した部分は殼長, 殻巾は平均值の両側に

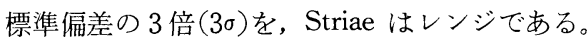

i ) Synedra ulna

相模湖のものは殼長, 殸巾で時期による違いはほとん ぞ認められず, Striae は1954年 8 月，1957年 4 月の試料 はモードが12本，1957年 7 月と1968年 9 月では11本とわ ずかな違いがある。

しかし相模湖の試料全体では殼長, 殸巾ならびに Striae ともヒストグラムは正規分布型となるので，区別を 


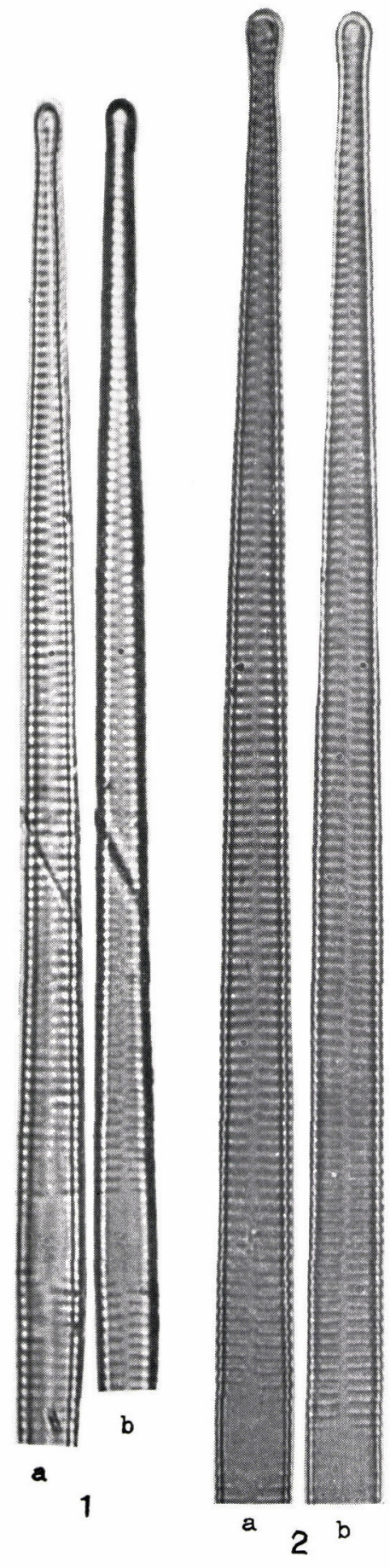

7. Synedra ulna

1. Sagami-ko 1954 August

2. Sagami-ko 1957 April

3. Sagami-ko 1957 July
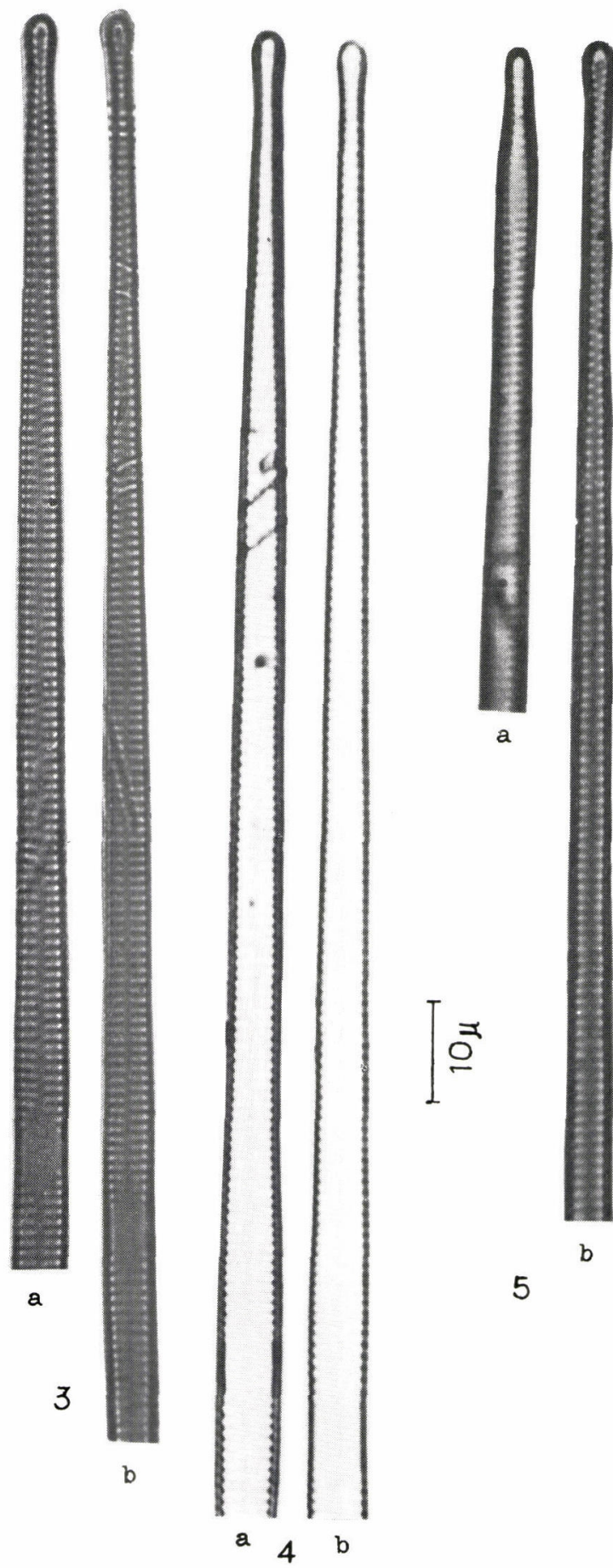

5

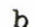

4. Sagami-ko 1968 September

5. Ashino-ko 1969 August 


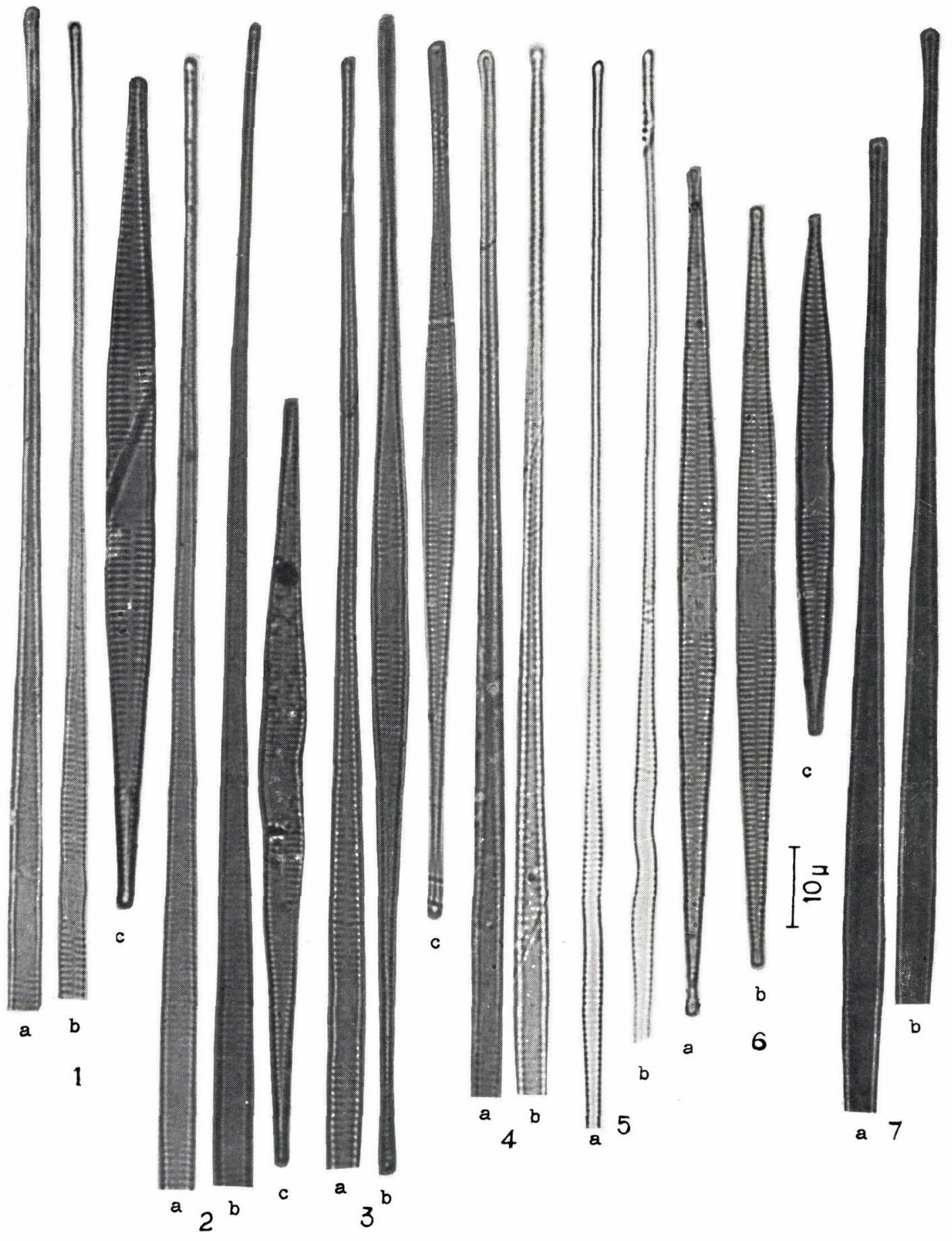

図 8. Synedra acus

1. Sagami-ko 1954 August

2. Sagami-ko 1957 April

5. Ashino-ko 1969 August

3. Sagami-ko 1957 July

6. Aichi-ike 1968 December

4. Sagami-ko 1967 February

7. Biwa-ko 1970 June 
表 3 Synadra ulna, Synedra acus の殸長, 殼巾, $10 \mu$ 中の Striae 数の計測値

\begin{tabular}{|c|c|c|c|c|c|c|c|c|c|c|}
\hline & & & & & & & & & & $\mathrm{L} / \mathrm{B}$ \\
\hline & & & $\mathrm{n}$ & mean & s.d. & mean & s.d. & mean & range & \\
\hline Synedra & & & & & & & & & & \\
\hline & 1954 & Aug. & 25 & 218.4 & 24.4 & 5.4 & 0.67 & 11.5 & $10-13$ & 40.4 \\
\hline Sagami-ko & 1957 & Apr. & 47 & 250.9 & 15.1 & 6.0 & 0.57 & 11.7 & $11-14$ & 41.8 \\
\hline & 1957 & July & 20 & 231.5 & 32.1 & 5.4 & 0.45 & 11.0 & $10-12$ & 42.9 \\
\hline & 1968 & Sept. & 52 & 275.4 & 26.7 & 5.5 & 0.40 & 10.8 & $10-12$ & 50.1 \\
\hline Ashino-ko & 1969 & Aug. & 48 & 230.5 & 15.5 & 4.7 & 0.35 & 10.3 & $9-11$ & 48.1 \\
\hline Synedra & & & & & & & & & & \\
\hline & 1954 & Aug. & 57 & 210.3 & 20.5 & 3.9 & 0.46 & 11.8 & $11-15$ & 52.6 \\
\hline Sagami-ko & 1957 & Apr. & 40 & 239.4 & 43.5 & 4.6 & 0.25 & 13.2 & $12-14$ & 52.0 \\
\hline & 1957 & July & 76 & 135.2 & 41.4 & 3.8 & 0.42 & 13.1 & $12-15$ & 39.8 \\
\hline & 1967 & Feb. & 42 & 225.3 & 17.2 & 3.3 & 0.36 & 11.3 & $9-13$ & 68.3 \\
\hline Ashino-ko & 1969 & Aug. & 49 & 204.9 & 14.2 & 2.5 & 0.27 & 14.9 & $13-16$ & 82.8 \\
\hline Aichi-ike & 1968 & Dec. & 67 & 98.4 & 20.3 & 4.7 & 0.39 & 14.1 & $13-15$ & 20.9 \\
\hline Biwa-ko & 1970 & June & 77 & 206.4 & 23.5 & 3.2 & 0.48 & 14.5 & $13-16$ & 64.5 \\
\hline
\end{tabular}

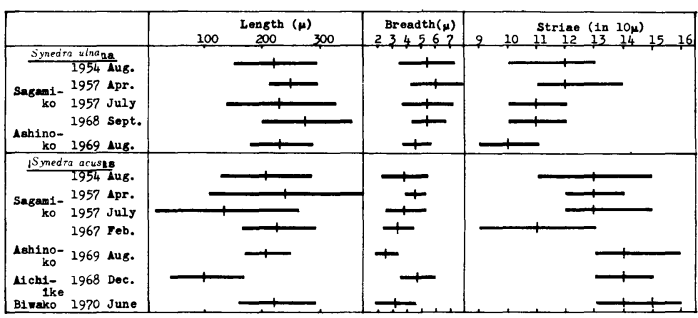

図 9. Synedra ulna, Synedra acus 殸長, 殸门 及び $10 \mu$ 中の Striae 数の Range

するほどの意味は無いと考えられる。

芦の湖のものは殼巾が $4.7 \mu$ とせまく，また Striae が 平均10.3本と相模湖のものより明らかに少ない。

ii) Synedra acus

相模湖のものは殼長一殼巾の比が 15 乃至 60 と変化があ るが，この変化は増殖の年や時期により特定の傾向は見 られない。Striae は2 月のものが11本と他の月のモード 13本に対し, やや少なかった。しかし殼長, 殸门ならび にStriae の試料全体でのヒストグラムはいずれも正規 分布型となる。

芦の湖のものは Striae が平均 14.9 本と多く，また殼 巾も同 $2.5 \mu$ と狭いので相模湖のものとは異なると思わ れる。

愛知池では殼長が短かく, 殼巾が広い，したがって殼 長一殻门の 比は調查した 4 湖沼の内, もっとも小さく 20.9である。Striae も13〜14 本と変化が少なかった。 琵琶湖のものは殼長一款巾の比が 64.5 と相模湖産に
近い。Striae は相模湖のものに比して多く 14 本以上の ものが多数みられた。

(3) 考察

外観ならびに計測值から見た相模湖の Synedra ulna, Synedra acus の両種はいずれも増殖の年あるいは時期 による決定的な相違点は認められず, 年や時期が異なっ ても, それぞれ同一の変種といえる。

Synedra ulna では外観, 計測值から Synedra ulna var. danica (Kütz.) Grun. に該当する。

Synedra acus は Fr. Hustedt ${ }^{5)}$ によれば基本型は殼 ゆが $5 \sim 6 \mu$, var. radians は $2 \sim 4 \mu$ としている。相 模湖のものの殼巾は $2 \sim 5.8 \mu$ であり, 基本型と var. radians が混在すると考えられるが，殼長や殼巾のヒス トグラムが正規分布型となるので両種の区別はつけがた い。

芦の湖でも Synedra ulna と Synedra acus の両種が みられたが, 同湖のSynedra ulna は頭端部の変化が著 るしいこと, 殸巾, Striae 数共に小さいことから相模湖 の変種とは別のものと考えられたが, 変種名の確認はで きなかった。

声の湖のSynedra acusは殼巾が狭く, 全体的に繊細 で Striae も多いことから Synedra acus var. angustissima Grun.に該当すると考える。

愛知池ならびに琵琶湖では Synedra acus のみで $S y$ nedra ulna はえられなかった。

愛知池のものは Synedra acus Kütz. の基本型であり, 琵琶湖のものは外観からは相模湖のものと区別し得ない。 
しかし Striae は相模湖のものより多く, var. angustissima に近いが，同変種よりも殼巾が広くSynedra acus var. radians (Kütz.) Hust.ではないかと考える。

\section{要結}

1. 湖や貯水池にしばしば大量に増殖し，これらの水 域を水源とする水道施設に沪過池閉塞や異臭などの障害 を生ぜしめる Synedra ulna, Synedra acus の增殖傾向 と水温, アルカリ度との関係を調査し，さらにそれぞれ の種について形態の検討を行なった。

2. 増殖傾向の調査は相模湖における1962年から1970 年の間の每月 1 回と西谷浄水場着水井における1970年の 毎週 2 乃至 3 回の調査資料を検討した。

3. 形態の調査はSynedra が優占的に増殖した時期 の相模湖 5 試料, 琵琶湖, 芦の湖, 愛知池の各々 1 試料 について外部形態の観察, 殸長, 殸巾, $10 \%$ 中の Striae 数の計測を行ない比烄検討した。

4. 相模湖の Synedra ulna, Synedra acus の増殖し た時の水温範囲は $6.8 \sim 29.0^{\circ} \mathrm{C}$ であり, 季節的には 3 月 〜12月に增殖が起っている。したがって両種の増殖の要 因として，水温の影響は一義的なものとはいえない。

5. 相模湖の過去 17 年間の Synedra の増殖とアルカ リ度の変動の傾向を符号検定したところ，有意水準 $5 \%$ で有意性が認められた。また増殖時と増殖時以外のそれ ぞれのアルカリ度のヒストグラムから母平均の差の検定 を行なった結果は，両者の母平均は異なるといえそうで ある。さらに1970年の浄水場着水井のアルカリ度と $S y$ nedra の遷移がかなり一致するなど，アルカリ度の上昇 期には Synedra の増殖が起りやすいといえそうである。

6. 相模湖に浮游性種として出現した Synedra ulna は形態の外観ならびに計測値から Synedra ulna var. danica (Kütz.) Grun. と同定した。同種は相模湖に前 述の如く，ほとんど季節を問わず増殖するが季節による 変異は特に認められない。芦の湖の種類は頭端部が var. danica 型, var, spathulifera 型, 両者の中間型と変化

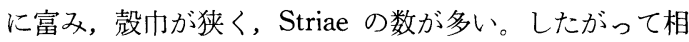
模湖の種類とは明らかに区別しらるが，種名の同定は出 来なかった。

7. 相模湖の Synedra acus は基本型と Synedra acus var. radians (Kütz.) Hust. が混在すると考えられるが, 殸巾や殼長のヒストグラムは正規分布型となり，両種の 間の変異は連続的であるので区別はつけがたい。また増 殖の時期による変異は特に認められなかった。芦の湖の ものは殼巾が狭く, 全体的に繊細でStriae 数も多いこと から Synedra acus var. angustissima Grun. と同定し た。愛知池のものは殼長が短かく殼巾が広い, Synedra acus Kütz. の基本種であり, 琵琶湖のものは Striae の 数が多く, 殼巾は狭いSynedra acus var. radians (Kütz.) Hust. ではないかと考える。

\section{参 考文 献}

1）乙幡恵: Synedra acus によるろ過障害とその処 理. 第 4 回日本水処理生物学会研究発表会要旨. 1942 .

2 ）小島貞男: 上水道の生物学(1). 用水之廃水, 9 , 10, 725 740. 1967 .

3) 梶正一: Synedra acus によるろ過障害について. 大阪府水道局水質試験所報告, No. 10. 1968 .

4) 八木正一：上水道に打忊生物起因の異臭の除去 について. バイオテク，2，10，講談社. 1971.

5 ) Hustedt, Fr. : Bacillariophyta. Heft 10 in A. Pascher (ed.). Die Süsswasser-flora Mitteleuropus. G. Fischer, Jena. 1930.

6 ) Patrick, R., Reimer, C. W. : The diatoms of the United States. vol. 1. The Academy of Natural Sciences of Philadelphia. 1966.

7 ）横浜市水道局水質試験所：水質試験成績並びに調 查報告. 第 5 集～第20集. 1954～1971．

8 ）津村考平 : 珪藻類の淸洗処理方法について. 藻類, 9, No. 1, 33〜36. 1961.

9 ）小出悟郎・高橋章 : 昭和 42 年 2 月に起った小雀浄 水場急速沪過池の閉塞障害. 日本水処理生物学会誌, 4, $1,1 \sim 5.1968$.

10）日科技連：二項確率紙の使い方. 1969.

11）小久保淸治：浮游珪藻類. 日本学術振興会. 1955 .

12）日本水道協会編：上水試験法(1960年版). 1960 .

13）松江吉行 ·平野礼次郎：水中の総炭酸量と植物プ ランクトン繁殖との関係について. 陸水誌, 17, 4, 133 〜 140. 1955 .

14）里見至弘：植物プランクトンの繁殖に適切な窒素 と燐の比とアルカリ度との関係. 淡水区水産研究所研究 報告, 8，2，21３9. 1959 . 